\title{
The Impact of Globalisation on Social Work Practice in Malaysia
}

Samir Muhazzab Amin \& Mohd Suhaimi Mohammad

To Link this Article: http://dx.doi.org/10.6007/IJARBSS/v11-i11/11658 DOI:10.6007/IJARBSS/v11-i11/11658

Received: 20 September 2021, Revised: 23 October 2021, Accepted: 04 November 2021

Published Online: 26 November 2021

In-Text Citation: (Amin \& Mohammad, 2021)

To Cite this Article: Amin, S. M., \& Mohammad, M. S. (2021). The Impact of Globalisation on Social Work Practice in Malaysia. International Journal of Academic Research in Business and Social Sciences, 11(11), 1753-1766.

\section{Copyright: (c) 2021 The Author(s)}

Published by Human Resource Management Academic Research Society (www.hrmars.com)

This article is published under the Creative Commons Attribution (CC BY 4.0) license. Anyone may reproduce, distribute, translate and create derivative works of this article (for both commercial and non0-commercial purposes), subject to full attribution to the original publication and authors. The full terms of this license may be seen at: http://creativecommons.org/licences/by/4.0/legalcode

\section{Vol. 11, No. 11, 2021, Pg. $1753-1766$}

Full Terms \& Conditions of access and use can be found at http://hrmars.com/index.php/pages/detail/publication-ethics 


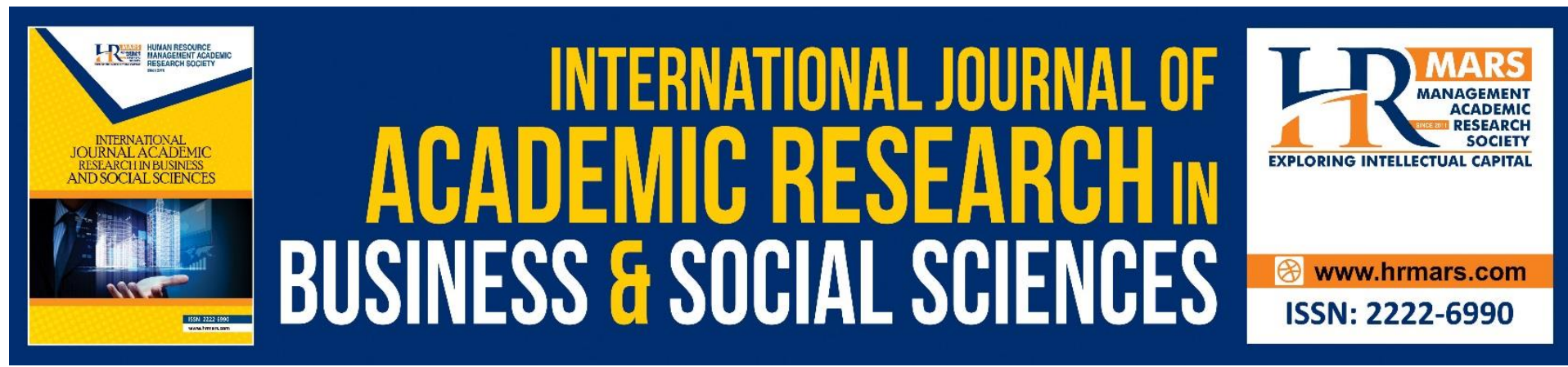

\title{
The Impact of Globalisation on Social Work Practice in Malaysia
}

\author{
Samir Muhazzab Amin ${ }^{1}$ \& Mohd Suhaimi Mohammad² \\ ${ }^{1}$ Department of Social Science and Development, Faculty of Human Ecology, University \\ Putra Malaysia, Serdang, Malaysia, ${ }^{2}$ Department of Psychology and Human Development, \\ Faculty of Social Sciences and Humanities, University Kebangsaan Malaysia, Bangi, Malaysia. \\ Email: samir@upm.edu.my
}

\begin{abstract}
Globalisation has significantly changed the pattern of social work including social development, economies, culture and environment in Malaysia. A measurable definition of globalisation has been described in this paper. The impact of globalisation on the Malaysian social work practice has transformed through the various stages of its development experience over the past decade. With this in mind, this paper is a review in which analysed the existing literature and highlighted the impacts of globalisation especially in Malaysia. The other main findings of the paper are that the globalism effect towards social work can be very diverse in different areas of the world including movement of people, culture, education and economy. There is a need to contextualize change in social work versus a broader political and economic context. Malaysia society has also posed many challenges in balancing needs and benefits with greater engagement with globalisation.
\end{abstract}

Keywords: Globalisation, Social Work, Social Work Practice, Education, Malaysia.

\section{Introduction}

Globalization is a collection of processes that converts conditions, relationships, and social forms into a form of globality while reducing national characteristics. Globalization can thus be characterised as the strengthening of worldwide social interactions that link distant locales in such a way that local happenings are impacted by events occurring many kilometres away and vice versa (Giddens, 1990). Globalization entails the establishment of new social networks and activities, as well as the expansion of existing ones, that cut over traditional political, economic, cultural, and geographic barriers. However, globalization is also contributing to the internationalisation of social problems, placing some social workers in situations where they must deal with issues that transcend national boundaries. It's revived old debates about international social work and spawned new demands for the twenty-first century.

Many scholars agree that social work practises are entrapped in the context of globalisation, which presents both new opportunities and challenges to their profession and the educational system (Lyons, 2006; Payne \& Askeland, 2008; Healy, 2008; Dominelli, 2010). Globalisation has traditionally played a significant impact in the emergence and subsequent development of Malaysia. Globalization's nature and impact, on the other hand, have evolved 
through time. Social work, according to the International Federation of Social Workers, is a practice-based profession and an academic discipline that promotes social change, development, social cohesion, empowerment, people's liberation, social justice, human rights, collective responsibility, respect for diversity, and engages people and structures to address life challenges and improve wellbeing. Around the world, social work is facing a time of fast development. Several causes, both external and internal to the profession, have contributed to and influenced the evolution of social work. Social work in developing nations has improved in order to assist individuals, families, groups, and communities in improving their abilities and collective welfare (Wilson, 2008; Zastrow, 2010; DuBois \& Miley, 2011; Sheafor et al., 2012).

The setting of changes in social work has been faced and encountered in Malaysia due to the existence of national specificity under the influences of economic globalisation. As a result, the purpose of this article is to investigate the impact of globalisation on social work in Malaysia at various stages of its growth. Social and economic progress, as well as structural change, will be covered. In addition, with reference to recent literature, three different definitions for social work will be considered. These are social work as a movement for universality in the profession and its standards, global social work as a practise, and social work as the profession's roles and impacts on the global stage and challenges.

\section{Study Purpose}

The article is divided into three main sections. The first part analyses the Systematic Literature Review (SLR). The second part focuses on the impact of globalisation on social work practice in Malaysia. The final part highlights on the challenges that social work practice in Malaysia faced as it strives to become a more prosperous and greater nation.

\section{Methods}

This is a systematic review on impact of globalisation on social work practice in Malaysia. The review was conducted through vigorous search in which related research based on several characteristics including instituting social work that occurs within the development of social work practice in Malaysia. The process to look for these particular articles was sought from two main journal databases which are Scopus and Web of Science. The author has identified the keyword used such as social work, globalism, globalisation for the search process. Throughout the flow, the review concurred on 15 articles which are relevant and appropriate to be reviewed for the current study (table 1). 
Table 1

Selected articles to assess the of impact of globalisation on social work practise in Malaysia

\begin{tabular}{|c|c|c|c|}
\hline $\begin{array}{l}\text { Title of research } \\
\text { article }\end{array}$ & Authors & Impact of globalism & Thematic arises \\
\hline $\begin{array}{l}\text { Globalization as a } \\
\text { challenge to } \\
\text { Islamic cultural } \\
\text { identity }\end{array}$ & Nurullah (2008) & $\begin{array}{l}\text { Globalization promotes media to } \\
\text { propagate the hegemony of } \\
\text { Western culture. It regenerates } \\
\text { local culture to replace it with the } \\
\text { Americanized secular one, and it } \\
\text { challenges the collective Islamic } \\
\text { ways of life, values, behavioral } \\
\text { patterns, and principles. }\end{array}$ & Issue and challenges \\
\hline $\begin{array}{l}\text { Globalization, } \\
\text { contemporary } \\
\text { challenges and } \\
\text { social work } \\
\text { practice }\end{array}$ & $\begin{array}{l}\text { Dominelli } \\
(2010)\end{array}$ & $\begin{array}{l}\text { Globalization has been } \\
\text { accompanied by the } \\
\text { internationalization of social } \\
\text { problems as issues that arise in } \\
\text { one location become problems in } \\
\text { another. }\end{array}$ & Issue and challenges \\
\hline $\begin{array}{l}\text { Impacts of } \\
\text { globalization on } \\
\text { economic change } \\
\text { and metropolitan } \\
\text { growth in } \\
\text { Malaysia: Some } \\
\text { regional } \\
\text { implications }\end{array}$ & $\begin{array}{l}\text { Rostam et al., } \\
(2010)\end{array}$ & $\begin{array}{l}\text { Economic social globalization } \\
\text { generates opportunities for } \\
\text { developed and developing } \\
\text { countries to gain access to } \\
\text { foreign markets. Liberalization of } \\
\text { trade policies has facilitated } \\
\text { movement of capital, people and } \\
\text { information across the world }\end{array}$ & $\begin{array}{l}\text { Issue and } \\
\text { opportunities }\end{array}$ \\
\hline $\begin{array}{l}\text { The impact of } \\
\text { globalization on } \\
\text { social work in UK }\end{array}$ & $\begin{array}{l}\text { Khan \& } \\
\text { Dominelli } \\
\text { (2010) }\end{array}$ & $\begin{array}{l}\text { Many of the changes that have } \\
\text { taken place can be attributed the } \\
\text { impact of globalization on } \\
\text { infrastructure, methods of work, } \\
\text { and the value of social work, and } \\
\text { in society. }\end{array}$ & Issues \\
\hline $\begin{array}{l}\text { Globalization and } \\
\text { the Malaysian } \\
\text { experience: } \\
\text { Upsides and } \\
\text { downsides }\end{array}$ & Poew (2011) & $\begin{array}{l}\text { Malaysia is affected by } \\
\text { globalization, especially in issues } \\
\text { related to education, culture and } \\
\text { identity. There are faced the } \\
\text { challenges of modernization in } \\
\text { preserving their traditions. } \\
\text { Malaysia has deliberately } \\
\text { attracted a large number of } \\
\text { foreign workers and following } \\
\text { that, the total number of foreign }\end{array}$ & Issues and response \\
\hline
\end{tabular}


workers in Malaysia is over two million.

\begin{abstract}
The effects of globalization on social work and
\end{abstract} youth justice

Does
globalization
have an impact in
the education
system in
Malaysia?

Globalisation and economic development: Malaysia's experience influenced the demand of the education system in Malaysia. The study focuses on four key aspects of education: trends in the demand for education based on education field, internationalization, lifelong learning, and the need of generic skills.

Cassey (2019)

From the pre-colonial until the post-independence period, Malaysia has been shaped by globalizations which are including trade, capital,

\begin{abstract}
Jurcevic \& Zivkovic (2011)

Possible ways of responding to globalization are exchange knowledge and information internationally and use it to improve social work practice. An effort in globalization process is the way of protection of citizens' and workers.
\end{abstract}

Othman (2012) Globalization gives an effect and technology, labor migration and the flow of information. Besides that, the premature deindustrialization has become a problem in Malaysia and this has been compounded by an overdependence on low-skilled foreign workers.

$\begin{array}{ll}\text { Starting the } & \text { Mohammed } \\ \text { indigenisation } & (2020) \\ \text { process of social } & \\ \text { work practice in } & \\ \text { Malaysia } & \end{array}$

Issues, challenges and responses

Issues

Issues and challenge Issues and challenge
Social work requires a theory that contains local culture elements that can be used to meet the needs of both people and their environments. There is a need to observe certain specific social, cultural and historical factors. The nature of social problems in Malaysia is completely different from proponents of current social work theory and field
Issues and challenges 
practices and roles for social workers. The current challenges of social work environment in Malaysia encompass the analysis of social needs reduced to micro levels at the individual and family levels.

Teaching poverty
in social work
classroom:
Perspectives from
global south and
policy
implications

Cultural globalization \& its impact upon Malaysian teenagers

Halim (2007)

\section{Global education} for social work: old debates and future directions for international social work.
Recognition and respect:
Healy (2014)

Three directions are appropriate for social work in the 21st century including forces to universalize aspects of the profession, identify global or international practice as an area of specialization and international professional organizations have done social work for an ambitious agenda to address global challenge.

Differences and cultures of Issues mutual respect globalization and
Issue and opportunities
Issues, impacts and challenges
Issues and opportunities 
Globalization

culture and

Malaysian

education

Impacts on the Zainudin \&

implementation Kamarudin

of social policy: (2015)

Comparative

study in Malaysia

and Indonesia recognition of the changes that have taken place is important to address language and the culture of globalization and education.

The impact of social policy on Issues, impacts and community development in opportunities Malaysia and Indonesia has been studied. Poverty eradication programs must help participants to achieve their social and economic well -being through empowerment in social and active investment participation in economic investment.

Challenges in an Pawi et al., informed society: (2020)

The impact of globalization on Malaysian cultural life
Impacts and challenges
Because of changes and impacts from the globalization process, all the traditional aspects, modernity, and critical thinking history and the present must be balanced as it can push society towards progress without unnecessary lifestyle and social behaviors. 


\section{Malaysia's Globalisation Phenomenon}

Globalisation has had a significant impact in the formation of Malaysia as a nation and its subsequent development. Almost every significant facet of globalisation, such as trade, capital, labour migration, technology, and information movements, has had a lasting impression on Malaysia's economy and society. Globalisation's nature and impact, on the other hand, have evolved through time. The introduction of Vision 2020 constituted a turning point in Malaysia's socio-cultural scene. It leads to a positive outlook on progress as a result of the establishment of the Multimedia Super Corridor, which has significant ramifications for Malaysians in becoming more informed citizens.

Malaysian society is both intricate and fascinating. It is one of Southeast Asia's most prosperous countries, with a multi-racial, multi-religious, multi-lingual, and multi-cultural population. Even more so, all races in Malaysia live and work in harmony, but there is no evidence of cultural absorption, in which each race develops its own customs, religion, education, and culture. As a result, they have experienced modernising issues in keeping their customs (Peow, 2011). Malaysia has a diverse population of races, including Malays, Chinese, Indians, and indigenous peoples like as the Kadazan, Iban, and Dusuns. Bumiputera people include both Malays and indigenous people. According to the Department of Statistics' Census of Population and Housing Malaysia 2020, the population of Malaysia is approximately divided as follows: Bumiputera 69.6 percent, Chinese 22.6 percent, Indian 6.8\%, and others $1 \%$.

Malaysian communities reacted to globalisation in tandem with the country's rapid social and economic development. Over 30 years ago, Malaysia's economy transitioned from an agrarian to an industrialised economy. It is currently being transformed into a knowledge economy. Furthermore, Malaysia must pursue a more open policy, not only economically, but also socially and culturally. Malaysian youth have more access to alternative media and are more open to different influences from around the world in order to achieve the following goals (Phua and Soo, 2004). Malaysia will be a developed nation by 2020, and it will have taken part in the declaration of Vision 2020. As a result, there has been an opening of the Malaysian market, migration of people in and out of Malaysia, and an opening up of education policy, all of which have characterised Malaysia's entry into a globalised period. Nonetheless, following the Asian economic crisis of 1997, Malaysia became more cautious in terms of economic liberalisation and other policies. Globalization does not always entail a reduction in the role of the state through liberalisation, deregulation, or privatisation. In many circumstances, dealing with globalisation necessitates a forceful intervention through reregulation, particularly when a country has institutional deficiencies and urgently requires government involvement to enhance its institutional framework. The Malaysian experience has proven that while rapid economic growth is necessary, it cannot guarantee social cohesion on its own. As a result, social policy design must be integrated into the overall development agenda. To be able to design the correct vision and implement the necessary policies, each country copying the Malaysian experience must take into account its own unique qualities (Mahmoud \& Mitkess, 2017)

In Malaysia, globalization has had a significant impact on social work practise, altering service delivery, changing the labour process for professional social workers, creating new social problems for practitioners to address, such as human trafficking and environmental issues, 
and resulting in calls for indigenization, or the development of locally specific forms of theory and practise. Particularly in the context of these developments for social work in Malaysia, social science research on the consequences and repercussions of globalisation has mostly focused on the benevolent state level and its implications for social policy. However, social work is all too often described as a regional subject, with an increased attention on practise difficulties (Dominelli et al., 2000). In addition to the foregoing, insufficient effort has been made to link these changes to broader global developments in order to create a conceptually rich understanding of social work changes. If social work is to gain greater legitimacy as a globally relevant subject, it must become increasingly entrenched in human rights.

\section{People's Movement}

Malaysia has purposefully drawn a large number of foreign workers since the 1980 s in order to accomplish a goal of being more competitive in industries such as agriculture, manufacturing, and construction. Simultaneously, it will work to reduce production costs, particularly those related to human resources. According to Peow (2011), Malaysia has a total population of over two million foreign workers. In addition to foreign labour, Malaysia has opened its doors to a wide range of other foreigners, including international students, businesspeople, and refugees. Globalisation has resulted in a huge number of foreigners populating several areas of the capital city, Kuala Lumpur. The preservation of citizens' and workers' rights, control of global capital movements, administration of transnational corporations, or the formation of non-governmental organisations (NGO's) require more effort in the globalisation process (Jurcevic \& Zivkovic, 2011). Non-governmental organisations (NGOs) have the power to respond to crises and battle against damaging global capital and transnational companies. Furthermore, non-governmental organisations (NGOs) can create a balance between transnational corporations and their globalisation aspirations (Payne \& Askeland, 2008).

\section{Culture}

People have defined culture in various ways. The various meanings of culture are based on the diversity in people's perspectives. Culture is a concept that is used to analyse and integrate events and ideas throughout a broad spectrum of societal sectors. Globalization has had a huge and varied impact on culture. It has influenced people's cultural aspects in various ways. Malaysia is a multiracial country with three primary ethnic groups: Chinese, Malayan, and Indian, as well as other minorities such as aborigines. Each racial group has its own culture, including religion, language, and education. As a result, in order to live in Malaysia in peace, we must first learn about their culture. In Malaysia, globalization has also resulted in a better understanding of different cultures. Globalization has aided in the improvement of interpersonal ties, just as you have experienced improved communication through virtual instruments such as the Internet. Globalization allows you to learn about different cultures and build a wider cultural understanding through the internet by googling information about the diverse social lifestyle of ethnics group in Malaysia.

However, globalisation also has a negative impact on Malaysia's social and cultural interactions, particularly in terms of ethnic relations. The increased enrolment in Chinese primary schools and Muslim religious institutions is an illustration of the globalisation effect. The rise in Chinese students enrolled in Chinese primary schools can be attributed to a number of factors, including the economic and educational benefits of learning Mandarin, 
particularly with China's rise as a major economic player, the declining quality of education in national primary schools, ethnic discrimination, the failure of multicultural education in national primary schools, and last but not least, the failure of multicultural education in national primary schools (Lee, 2006). Aside from that, there has been a growing emphasis on studying Mandarin, which has been supported by a commensurate emphasis on learning English. As a result of globalisation, English and Mandarin are now perhaps the most important languages on the planet. Globalisation, on the other hand, poses a threat to Islamic cultural identity. According Nurullah and Rahman (2012), Western culture's hegemony through the media, regenerates local culture to replace it with Americanized secular culture, and challenges collective Islamic ways of life, values, behavioural patterns, and principles.

Malaysia has also looked on the effects of globalisation on teenagers. In Malaysia, these categories of people, who include students and teenagers, are the ones who are most affected by the globalisation process (Shairi, 2001). This is because, between the ages of 10 and 24, adolescents are seeking for their identity, experimenting with culturally diverse settings, and discovering new things. At the same time, we referred to it as a phase of transition from child to adult. The impact of globalisation on the population, particularly young people, includes cultural and social modern lives. The globalisation culture and modern lifestyle have had an impact on three aspects: cuisine, fashion, and consumerism. In general, integration of global culture into Malaysian customs is defined as the instillation of western style and ideals in local food and fashion (Pileh, 2001; Zakaria, 2001). Fast foods and styles have gradually eroded the popularity of traditional national cultures around the world (Ahmad, 2000). As a result, we must improve the value system in each individual, family, and society in order to meet the problems brought by globalisation. It is also everyone's responsibility to protect the dignity of local culture and heritage (Halim, 2007).

\section{Education}

The globalisation of the social work education system has become a common occurrence in Malaysia, which is both a developing country and an exceptional educational centre. Malaysian social work education is in the midst of a transformation. There are clear efforts to connect the profession with worldwide benchmarks through social work education and training in order to increase the profession's level (Turner, 2017; Amin et. al., 2019). To succeed in a globally competitive economy, a country's education system must be able to meet the demands of the economic sector, including in terms of knowledge and skilled personnel. Globalisation pressures, such as worldwide political conflicts, global markets, and global communication systems, have influenced the change of higher education institutions (Ismail \& Idris, 2007).

The National Higher Education Strategic Plan Beyond 2020, for example, has exposed the transformation of institutions of higher education by providing a framework within which measures can be made to generate human capital with a first-class attitude. Widening access and increasing equity; improving the quality of teaching and learning; enhancing research and innovation; strengthening higher education institutions; intensifying internationalisation; enculturation of lifelong learning; and reinforcing the Ministry of Higher Education's delivery systems are the seven thrusts that have been identified to strengthen and revolt education (Othman, 2012). According to Tan (2002), global forces have a significant impact on country states to change policy in order to increase access to higher education in order to develop 
human capital, enhance national competitiveness, and catch up with the realities of globalisation. As a result, Malaysia's institutions must adapt to changes in the globalising world in order to meet political, economic, and social needs.

\section{Economy}

Malaysia's formation as a nation is a good place to start when looking at the effects of globalisation on the country. Malaysia's economic development has been heavily influenced and impacted by globalisation, particularly throughout the pre-colonial, colonial, and postindependence periods. Every facet of globalisation, including commerce, capital, technology, labour migration, and information flow, has had a significant impact on Malaysia's economy and society (Cassey, 2019). Chuah et al (2018) used microdata from three manufacturing censuses $(2000,2005$, and 2010) to investigate resource reallocation within sectors. The authors discovered that export-oriented industries are generally more efficient at resource allocation in terms of globalisation. Textile, wood products, and electrical and electronics industries were among these businesses. Aside from that, the authors discovered that the productivity gap between Malaysia and the US has expanded over time. The global economic wave in Malaysia has changed not only the country's economic structure, but also the distribution of its people and wealth, as has already occurred in major cities. Previously, Malaysia's GDP grew at a rapid rate of 6.0-9.5 percent on average from 1970 to 1997, but subsequently fell from 1998 to 2005 due to economic downturn caused by the Asian financial crisis. However, the economy has been recovering well, with an annual growth rate of 5.3 percent (Ismail, 2008). Malaysia's administration has undoubtedly promoted rapid industrialisation in order to strengthen the country's economy. As a result of recent economic developments brought about by globalisation, Malaysia's economy has switched from manufacturing to service sectors (Rostam et al., 2010).

\section{Moving Forward}

By the process of globalisation in Malaysia, the new values created are inevitable and can be seen from a historical and socio-cultural perspective since the early $20^{\text {th }}$ century. Even though Malaysia is relatively small country in the world community, it is very careful in navigating the global current and response to the challenges posed in the process. Therefore, as Malaysia has become more globalize, then it has not become more secularize as predicted by some globalisation and modernization theories. Since 1990s, not surprisingly that premature deindustrialization has become a problem in Malaysia and this has been compounded by an over-dependence on low-skilled foreign workers. However, extensive government ownership in the services sector to achieve decisive action and wealth redistribution goals can also limit the potential contribution of this sector to economy development (Cassey, 2019). This can affect service productivity sector and restrict national participation in new regional trade agreements. From a policy perspective, better policy institutions and instruments are needed to address this with the risks arising from globalisation. The increase in institutions also tends to increase the competitiveness of Malaysia's trade.

At all the state of the process of globalisation, the traditional, modern, and historical aspects of critical thinking and the present must be balanced because it can push social work towards progress without unnecessary lifestyle and social behaviors. In today's contemporary Malaysian world, there is a need to educate and train social work graduates to work with marginalized groups affected by open borders thus lead to the globalisation of poverty. 
Perspective building graduates of social work in the classroom as well as in practice are essential as students attitudes toward poverty are known to influence the way they treat inclined individuals to be poor. Social work education has an important role in the development of critical awareness among students. With this in mind, educational programs in social work are offered at social work schools throughout globe are actually aims to develop the skills needed for social work graduates to overcome poverty and vulnerable groups (Jianguo, 2020). Thus, social workers will further use skills such as consultation and party involvement of individuals, families, communities and population groups.

As Malaysia has a big and complex community known as the National Social Policy, hence it can be said that the development of social policy is becoming increasingly important to manage it. The identification of social work practices in Malaysia must be in the social, cultural, political and economic contexts. According to Zainudin (2021), he stated that Malaysia has to integrate its social policies with economic policies to create political unity, social stability, and social equality through the years. Consequently, Malaysia has to take an approach to centralize its role in the development and growth of the country's economy for the nation. On the other hand, the practice of social work needs to be subjected to critical and theoretical analysis in the context of the country. For example, the current challenges of social work environment in Malaysia encompass the analysis of social needs reduced to micro levels at the individual and family levels (Mohammed, 2020). In addition to the large emphasis on employment, government social welfare officers focus on eligibility for services rather than a comprehensive assessment of needs and issues to create an intervention strategy. Hence forward, the need to conceptualize and redefine social work training properly in the Malaysian context is very important and thus consider native.

\section{Conclusion}

Social work is in a state of change and old certainty practice is challenged. Social work principles are based on respect for the equality, worth, and dignity of all humans, and it emerged from humanitarian and democratic values. There is no denying that Malaysia is influenced and affected by globalisation. Many of the ensuing changes can be attributed to the impact of globalisation on the movement of people, culture, education and economy has been focused on these aspects. Despite the risks of globalisation, escaping globalisation is not an option for the Malaysian economy due to its small size. Placing social goals at the centre of every development strategy ensures two things: economic growth can be achieved while maintaining equity, and sustainable development cannot be achieved while ignoring social concerns. Therefore, from a fundamental perspective, the policy instruments and better institutions are needed to address the risks raised from globalisation.

\section{Acknowledgement}

We are grateful to our faculty members for their insights and expertise, which greatly aided in the writing on the paper.

\section{Disclosure Statement}

No potential conflict of interest was reported by the authors. 


\section{References}

Dominelli, L. (2010). Globalisation, contemporary challenges and social work practice. International Social Work, 53(5), 599-612.

Amin, S. M., Mohamad, M. S., \& Ahmad, T. L. T. (2019). The development of social work undergraduate programs in Malaysia public universities: Issues, challenges and opportunities. Towards a Safer World: Addressing the Dynamics of Human Ecological Challenges, 45.

Cassey, L. E. E. (2019). Globalisation and Economic Development: Malaysia's Experience. ERIA Discussion Paper Series, 307.

Chuah, L. L., Loayza, N., \& Minh, N. H. (2018), 'Resource Misallocation and Productivity Gaps in Malaysia', Policy Research Working Paper, No. 8368.Washington, DC: World Bank Group.

Dominelli, L., Pierce, R., \& Weinstock, J. (2000). International comparisons in social work. London.

DuBois, B., \& Miley, K. K. (2011). Social work: An empowering profession (7th ed.). Boston, MA: Allyn \& Bacon.

Halim, A. A. (2007). Cultural globalisation \& its impact upon Malaysian teenagers. Jurnal Pengajian Umum Bil, 8(18), 0.

Healy, L. M. (2008). International social work: professional action in an interdependent World. NY: Oxford University Press.

Ismail, R., \& Idris, N. A. (2007). Globalisasi dan daya saing global: satu tinjauan. Pembangunan sumber manusia dalam era k-ekonomi" in Pembangunan SumberManusia dalam Era KEkonomi, Rahmah. Ismail, Nor Aini Idris, Razak Mohd, Eds.Bangi: Penerbit Universiti Kebangsaan, 17-32.

Ismail, N. W. (2008). Growth and convergence in ASEAN: A dynamic panel approach. International Economy Manage, 2, 127-140.

Jianguo, G., Baikady, R., Sajid, S. M., Shengli, C., \& Yuxiang, W. (2020). Teaching poverty in social work classroom: perspectives from global south and policy implications. Social Work \& Society, 18(2).

Jurcevic, R., \& Zivkovic, M. (2011). The effects of globalisation on social work and youth justice. Dialogue in Praxis-A Social Work International Journal, (0 (21)), 35-43.

Lee, H. G. (2006). "Globalisation and ethnic integration in Malaysia" in Saw, S. H. \& Kesavapany, K. (ed.). Malaysia: Recent Trends and Challenges. Singapore: ISEAS.

Lyons, K. (2006). Globalisation and social work: international and local implications. British Journal of Social Work, 36(3): 365-80.

Mohmoud, M. S., \& Mitkees, H. (2017). Malaysia's Vision 2020 and the Role of Leadership in Economic Development. Asia Social Science, 13(8) 49 - 58.

Mohammed, A. A., Uddin, M. S., \& Bougangue, B. (2020). Starting the Indigenisation Process of Social Work Practice in Malaysia. Social Work \& Society, 18(1).

Nurullah, A. S. (2008). Globalisation as a challenge to Islamic cultural identity. International Journal of Interdisciplinary Social Sciences, 3(6), 45-52.

Othman, N. (2012). Does Globalisation have an Impact on the Education System in Malaysia? International Journal of Learning, 18(9).

Payne, M., \& Askeland, G. A. (2008). Globalisation and International Social Work: Postmodern Change and Challenge. Abingdon.

Peow, S. H. (2011). Globalisation and the Malaysian Experience: Upsides and Downsides. Journal of Asia Pacific Studies, 2(1). 
Phua, K. L., \& Soo, K. S. (2004). What's Ahead for Malaysia? Contemporary Challenges and Emerging Trends. Kuala Lumpur: Pelanduk Publications Sdn Bhd.

Rahman, S. A., \& Nurullah, A. S. (2012). Islamic Awakening and its Role in Islamic Solidarity in Malaysia. American Journal of Islamic Social Sciences, 29 (1), 98-125.

Rostam, K., Mat Jali, M.F. \& Toriman, M.E. (2010). Impacts of globalisation on economic change and metropolitan growth in Malaysia: Some regional implications. The Sosial Science, 55 (4), 292-301.

Sheafor, B. W., Morales, A., \& Scott, M. E. (2012). Social Work: A Profession of Many Faces. Boston, MA: Allyn \& Bacon.

Tan, A. M. (2002). Malaysian Private Higher Education. Asean Academic Press Ltd.

Turner, F. J. (2017). Social Work Treatment: Interlocking Theoretical Approaches (6th ed.). Oxford, New York: Oxford University Press.

Wilson, K. (2008). Social Work: An Introduction to Contemporary Practice. New York, USA: Pearson Education.

Zainudin, M. Z. (2021). Social policy implementation in malaysia and its impact on the community. In Social Policy in the Islamic World (pp. 263-278). Palgrave Macmillan, Cham.

Zastrow, C. (2010). Introduction to Social Work and Social Welfare: Empowering People (10th ed.). Belmont: Brooks/Cole, Cengage Learning 